\title{
Insights into the factors responsible for curative effects of Aab-E-Shifa Spring Hasan Abdal (Pakistan)
}

\author{
Sami ur Rahman ${ }^{1} \cdot$ Salma Bilal $^{1}$
}

Received: 4 May 2015/Accepted: 14 September 2015/Published online: 24 October 2015

(c) The Author(s) 2015. This article is published with open access at Springerlink.com

\begin{abstract}
Springs are the gifts of nature on the earth as they contribute about eighty essential nutrients that are involved in more than 7000 enzymatic processes in the human body. European balneologists have recommended spring mineral waters for different therapeutic applications. In the present investigation, Aab-e-Shifa (Punjab Pakistan) spring water was analyzed due to its therapeutic behavior in the healing of various skin diseases via atomic absorption spectroscopy (AAS). It was found that besides other important minerals $(\mathrm{Ca}, \mathrm{Mg}, \mathrm{K}$, and $\mathrm{Na}$ ), the spring water contains the most significant antioxidant, i.e., $\mathrm{Zn}$ which is probably one of the major features of the curative behavior of Aab-e-Shifa. Other trace elements $(\mathrm{Cr}, \mathrm{Cd}, \mathrm{Ni}, \mathrm{Mn}, \mathrm{Fe}$, and $\mathrm{Cu}$ ) were also found to be present in the spring water under the permissible limits of various national and international organizations.
\end{abstract}

Keywords Aab-e-Shifa Spring · AAS · Zn Concentration . Trace Elements

\section{Introduction}

The art of healing diseases comes from nature, not from the physician. Therefore, the physician must start from nature with an open mind rather his/her own skills. Development in the area of medicine brought about a great change in this approach. Therefore, physician and scientists began to believe more and more in their own skills and ability to

Sami ur Rahman

samiurrahman364@yahoo.com

1 National Center of Excellence in Physical Chemistry, University of Peshawar, Peshawar 25120, Pakistan intervene in the process of nature to influence and change them. This rapid development in the science of medicine has resulted in newly emerging drugs and almost neglected natural mending processes and disparagement of every method of healing that was not identified with conventional medicine. In recent years, there is a serious trend toward a "return to nature," that is an approach to natural methods of treatment. Among them, one is the use of natural spring water for therapeutic purposes (Lucio and Laura 1995).

Spring water is a natural solution formed under definite geological conditions. Such waters are characterized via physico-chemical dynamism. It is believed that spring (mineral) water looses most of its insubstantial properties when far removed from its source. It is difficult to prepare artificial mineral water because of the absence of biological activities under which natural mineral water is formed (Lotti and Ghersetich 1996a, 1996b). Throughout the world, people use mineral spring water for bathing and their health for thousands of years. For example, with in Japan, there are about 2500 hot water springs, and approximately 150 million people use these spring water for bathing and for health care every year.

The international usage of spring mineral water has been reported by various authors (Hotta and Ishiguaro 1992; Lund 1993; Geo-Heat Centre 1993; Cataldi et al. 1999). The Romans used spring water for the treatment of eyes and skin diseases. In Europe, USA, New Zealand, and Mexico, the natural hot springs have been very famous for health attraction. But Japan is considered to be the World's leader in Balneology (Latin: Balneum, bath) (Kaysing 1990; Itallie et al. 1988; Sarnoff 1989; Litton 1990). In USA, visiting hot mineral springs for the cure of a variety of skin diseases once popular has fallen out of favor now. The reason is that modern medicine becomes more efficient and health care became nationalized. However, the practice 
of balneotherapy is still more well-liked in some European countries and going to a hot spring "cure" is included in medical insurance (Finkelman 2006). Mineral springs and thermal muds have also been used to sooth and cure a variety of ailments since antiquity which constitutes the basis of spa (Fountain) therapy (Riyaz and Arakkal 2011).

In hot spring water, there are about 80 vital nutrients and it has been investigated that about 7000 enzymatic processes are involved during metabolism in human body that requires both minerals and trace elements. Common elements found in these remedial hot spring waters are believed to be therapeutic in nature. The healing effect of spring water is mostly due to the chemical influence of minerals which are transferred to the skin and the blood stream by the process of osmosis (Javed et al. 2009). The physical effects of spring water are owing to the water temperature which facilitates the dilation of skin for oxygen flow in the tissues that are being treated (Lotti and Ghersetich 1996a, 1996b). The mineral properties of spring water differ from area to area and even from spring to spring. This is why each spring has different curative properties depending on its mineral contents.

In district Attock (Punjab), a hot spring famous with the name of Aab-e-Shifa is located in Hasan Abdal town about $7 \mathrm{~km}$ south of the main city. A large number of people from all over the country visit the Aab-e-Shifa spring. They bath there with water of the spring and drink it (Figs. 1, 2, $3,4)$, to get rid of various skin diseases and allergies such as acne, scabies, and ringworm. The people who visited Aab-e-Shifa observed immense therapeutic effects of the water on various skin and other diseases of their body.

Due to the paramount interest and growing use of the Aab-e-Shifa water for skin diseases and other body disorders, a need was felt for rigorous scientific approach to evaluate the therapeutic properties of minerals present in Aab-e-Shifa water. It is a naturally thermal mineral water

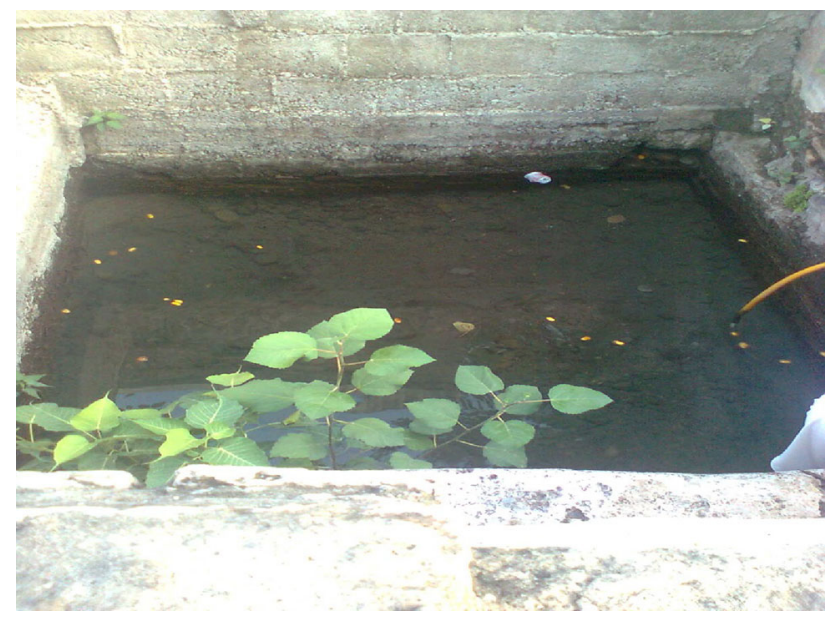

Fig. 1 Location Spot of Aab-e-Shifa (BaBa Shah Gharib Hasan Abdal)

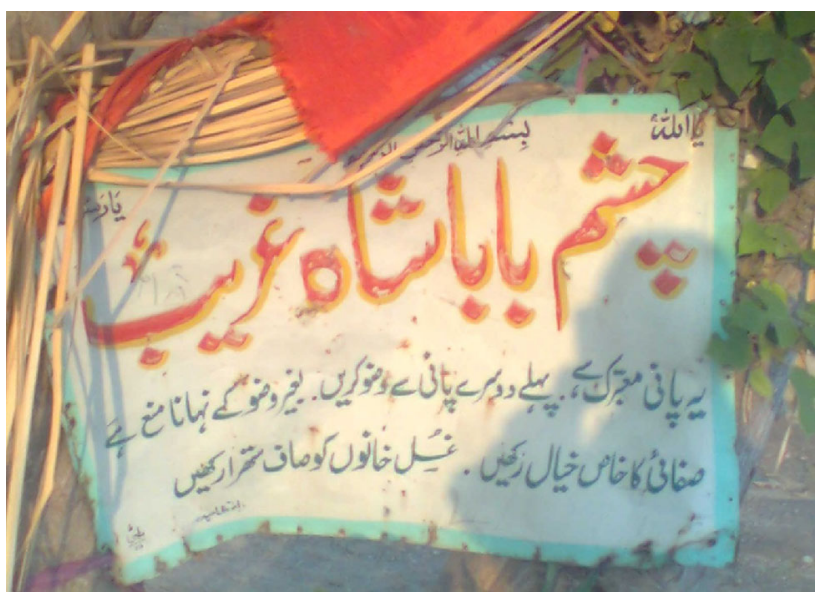

Fig. 2 Aab-e-Shifa Sign Board

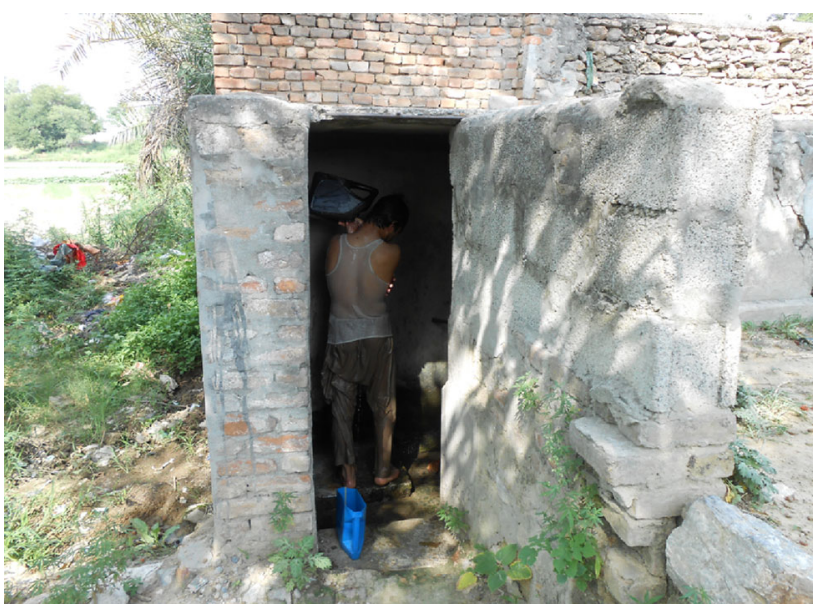

Fig. 3 Male Bathroom of Aab-e-Shifa

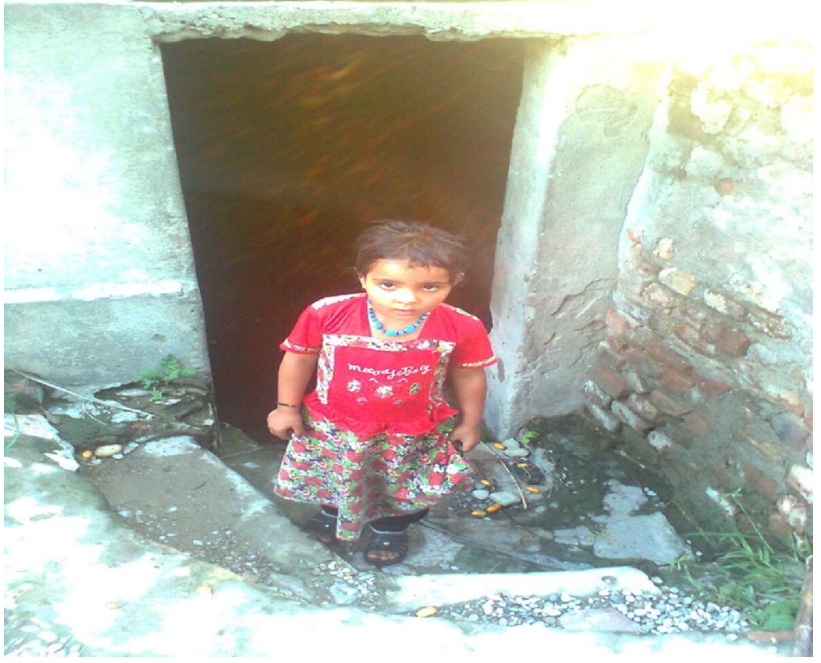

Fig. 4 Female Bathroom of Aab-e-Shifa 
sustained at $34{ }^{\circ} \mathrm{C}$. Aab-e-Shifa contain important minerals $\mathrm{Na}, \mathrm{K}, \mathrm{Ca}, \mathrm{Mg}$, and the most essential trace element $\mathrm{Zn}$ which is more effective for skin diseases and other body disorders. Besides $\mathrm{Zn}$, it also contains other trace elements such as, $\mathrm{Fe}, \mathrm{Cu}, \mathrm{Ni}, \mathrm{Mn}, \mathrm{Cd}$, and $\mathrm{Cr}$, but the concentrations of these elements are very low and below the limit of toxicity. To investigate the distinguishability of Aab-eShifa water, samples of water from village houses were also analyzed (Table 1 and Figs. 5, 6 ). It was found that Aab-e-Shifa water is unique in this character as compared to the village house's drinking water.

\section{Materials and methods}

\section{Sampling}

2.25 Liter clean polythene screw-capped bottles were used to collect the samples three times from the site. Each sample bottle was washed with a brush and phosphate-free detergent, three times with tap water, soaked in $10 \%$ hydrochloric acid, again washed with tap water, and finally rinsed three times with deionized water. Then, these bottles were dried in sun light and kept in oven at $60{ }^{\circ} \mathrm{C}$ for $12 \mathrm{~h}$, cooled to room temperature, recapped, and labeled before collection of samples. Six drinking water samples for comparison with Aab-e-Shifa were also collected from different locations. Three samples (1, 2, and 3) were collected from tube wells within the houses and the remaining three samples $(4,5$, and 6) from drinking water springs in different areas of the Hasan Abdal town. At the time of sampling, bottles were rinsed with samples water. All necessary measures were taken during samples filling, transport, and storage. Before starting the analysis, all the glassware was washed on the same procedure as the samples bottles were washed along with $20 \% \mathrm{HNO}_{3}$.

\section{Physico-chemical analysis}

Temperature of the samples was determined by commonly used mercury thermometer. $\mathrm{pH}$ was recorded by $\mathrm{pH}$ meter

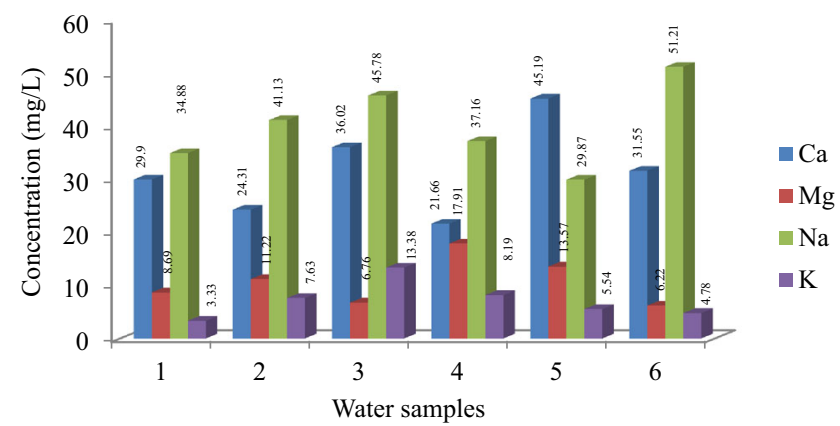

Fig. 5 Concentration of $\mathrm{Ca}, \mathrm{Mg}, \mathrm{Na}$, and $\mathrm{K}$ in the drinking water of the village water in the form of bar chart

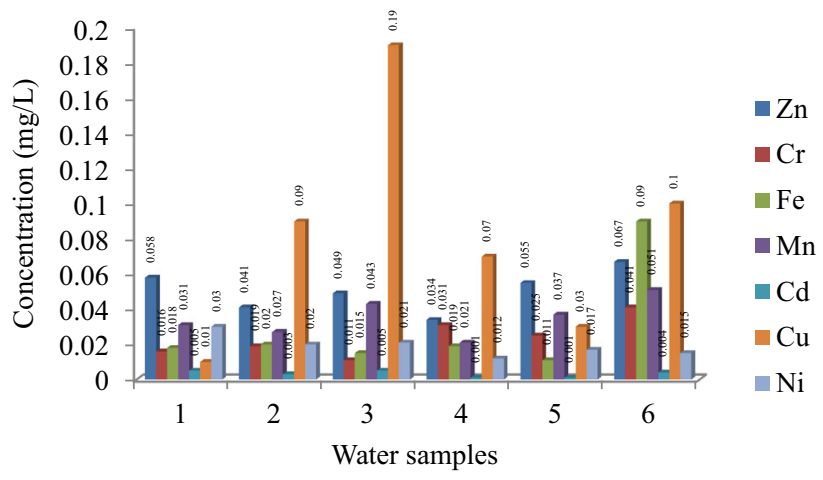

Fig. 6 Concentration of $\mathrm{Zn}, \mathrm{Cr}, \mathrm{Fe}, \mathrm{Mn}, \mathrm{Cd}, \mathrm{Cu}$, and $\mathrm{Ni}$ in the drinking water of the Village in the form of bar chart

(Model: iSTEK pH/ISE Meter pH-250L). All filtered and acidified water samples $\left(5 \mathrm{~mL} \mathrm{HNO}_{3}\right.$ in $100 \mathrm{~mL}$ of water) were analyzed for heavy metals $(\mathrm{Cr}, \mathrm{Cd}, \mathrm{Cu}, \mathrm{Fe}, \mathrm{Ni}, \mathrm{Mn}$, and $\mathrm{Zn}$ ) and light metals ( $\mathrm{Na}, \mathrm{K}, \mathrm{Ca}, \mathrm{Mg}$ ) with the help of graphite furnace atomic absorption spectrometer (AAS) (Perkin-Elmer AAS-700). For quality control assurance, each water sample was analyzed in triplicate, and the mean values were calculated. Standard working solutions for all eleven (11) concerned metals were prepared by appropriate dilution of $1000 \mathrm{mg} / \mathrm{L}$ certified standard solutions Fluka Chemica (Buchs, Switzerland) of the corresponding metals in double-deionized water. All the chemicals used during

Table 1 Temperature, $\mathrm{pH}$, and Concentration of $\mathrm{Na}, \mathrm{K}, \mathrm{Ca}, \mathrm{Mg}, \mathrm{Zn}, \mathrm{Fe}, \mathrm{Cr}, \mathrm{Cd}, \mathrm{Mn}, \mathrm{Ni}$, and $\mathrm{Cu}$ in $\mathrm{mg} / \mathrm{L}$ in the drinking water of the village houses

\begin{tabular}{llllllllllllll}
\hline S. & $\begin{array}{l}\mathrm{T} \\
\mathrm{ID} .\end{array}$ & $\begin{array}{l}\left.{ }^{\circ} \mathrm{C}\right) \\
\mathrm{pH}\end{array}$ & $\begin{array}{l}\mathrm{Ca}(\mathrm{mg}) \\
\mathrm{L})\end{array}$ & $\begin{array}{l}\mathrm{Cd}(\mathrm{mg} / \\
\mathrm{L})\end{array}$ & $\begin{array}{l}\mathrm{Cr}(\mathrm{mg} / \\
\mathrm{L})\end{array}$ & $\begin{array}{l}\mathrm{Cu}(\mathrm{mg} / \\
\mathrm{L})\end{array}$ & $\begin{array}{l}\mathrm{Fe}(\mathrm{mg} / \\
\mathrm{L})\end{array}$ & $\begin{array}{l}\mathrm{K}(\mathrm{mg} / \\
\mathrm{L})\end{array}$ & $\begin{array}{l}\mathrm{Mg}(\mathrm{mg} / \\
\mathrm{L})\end{array}$ & $\begin{array}{l}\mathrm{Mn}(\mathrm{mg} / \\
\mathrm{L})\end{array}$ & $\begin{array}{l}\mathrm{Na}(\mathrm{mg} / \\
\mathrm{L})\end{array}$ & $\begin{array}{l}\mathrm{Ni}(\mathrm{mg} / \\
\mathrm{L})\end{array}$ & $\begin{array}{l}\mathrm{Mg}(\mathrm{mg} / \\
\mathrm{L})\end{array}$ \\
\hline 1 & 25 & 7.42 & 29.90 & 0.005 & 0.016 & 0.01 & 0.018 & 3.33 & 8.69 & 0.031 & 34.88 & 0.030 & 0.058 \\
2 & 24.8 & 7.43 & 24.31 & 0.003 & 0.019 & 0.09 & 0.020 & 7.78 & 11.22 & 0.027 & 41.13 & 0.020 & 0.041 \\
3 & 24.5 & 7.48 & 36.02 & 0.005 & 0.011 & 0.19 & 0.015 & 13.38 & 6.76 & 0.043 & 45.78 & 0.021 & 0.049 \\
4 & 23 & 7.45 & 21.66 & 0.001 & 0.031 & 0.07 & 0.019 & 8.19 & 17.91 & 0.021 & 37.16 & 0.012 & 0.034 \\
5 & 22.5 & 7.47 & 45.19 & 0.001 & 0.025 & 0.03 & 0.011 & 5.54 & 13.57 & 0.037 & 29.87 & 0.017 & 0.055 \\
6 & 23 & 7.49 & 6.22 & 0.004 & 0.041 & 0.10 & 0.090 & 4.78 & 6.22 & 0.051 & 51.21 & 0.015 & 0.067 \\
\hline
\end{tabular}


Table 2 Wavelengths used for the determination of various metals

\begin{tabular}{lll}
\hline S. no. & Metal & Wavelength $(\mathrm{nm})$ \\
\hline 1 & $\mathrm{Ca}$ & 422.7 \\
2 & $\mathrm{Cd}$ & 228.8 \\
3 & $\mathrm{Cr}$ & 357.9 \\
4 & $\mathrm{Cu}$ & 324.8 \\
5 & $\mathrm{Fe}$ & 248.3 \\
6 & $\mathrm{~K}$ & 766.5 \\
7 & $\mathrm{Mg}$ & 285.2 \\
8 & $\mathrm{Mn}$ & 279.5 \\
9 & $\mathrm{Na}$ & 589 \\
10 & $\mathrm{Ni}$ & 232 \\
11 & $\mathrm{Zn}$ & 213.9 \\
\hline
\end{tabular}

analysis were of analytical grade. All these analyses for heavy metals and light metals were carried out in central research laboratory (CRL), University of Peshawar, Pakistan.

The working conditions of AAS are listed below:

Model: Perkin-Elmer AAS-700, Carrier Gas: Acetylene gas, Oxidant: Compressed air, Flame temperature: $2500{ }^{\circ} \mathrm{C}$, Lamp: Hollow cathode lamp (HCL), Lamp type: Neon HCL, Gas flow: $2.5 \mathrm{~L} / \mathrm{min}$, Air flow: $5 \mathrm{~L} / \mathrm{min}$, and Gas pressure: 80 PSI. Wavelengths used for the determination of metals given in Table 2.

\section{Results and discussion}

Antioxidants whether natural or synthetic play a significant role in maintaining healthy skin. However, what nature's heals cannot be compensated with synthetic drugs. In this connection, we explored the therapeutic properties of the Aab-e-Shifa water for the first time. It contains important minerals $\mathrm{Na}, \mathrm{K}, \mathrm{Ca}, \mathrm{Mg}$, and the most essential trace element $\mathrm{Zn}$ (Table 3 and Figs. 7, 8), which is very important and helpful antioxidant and provides defense for skin (Elizabeth et al. 2002). Other trace elements such as $\mathrm{Fe}, \mathrm{Cu}$, $\mathrm{Ni}, \mathrm{Mn}, \mathrm{Cd}$, and $\mathrm{Cr}$ were also determined (Table 3 and Fig. 8), but the concentration of these elements is very low in the water and below the limits of toxicity.

In Aab-e-Shifa water, the concentration of $\mathrm{Zn}$ is $6.73 \mathrm{mg} / \mathrm{L}$ (Table 3 and Fig. 8). The high concentration of $\mathrm{Zn}$ in this water is assumed to be due to $\mathrm{Zn}$-based minerals in the soils and rocks of this specific area where the spring is present. The concentrations of other trace elements are $\mathrm{Fe}(0.03 \mathrm{mg} / \mathrm{L}), \mathrm{Cu}(0.012 \mathrm{mg} / \mathrm{L}), \mathrm{Ni}(0.018 \mathrm{mg} / \mathrm{L}), \mathrm{Mn}$ $(0.016 \mathrm{mg} / \mathrm{L}), \mathrm{Cd}(0.006 \mathrm{mg} / \mathrm{L}), \mathrm{Cr}(0.008 \mathrm{mg} / \mathrm{L})$, and the temperature is sustained at $34{ }^{\circ} \mathrm{C}$ with a pH of 7.86 (Table 3 ). Furthermore, the water also contains certain
Table 3 Temperature, $\mathrm{pH}$, and Concentration of $\mathrm{Na}, \mathrm{K}, \mathrm{Ca}, \mathrm{Mg}, \mathrm{Zn}$, $\mathrm{Fe}, \mathrm{Cr}, \mathrm{Cd}, \mathrm{Mn}, \mathrm{Ni}$, and $\mathrm{Cu}$ in $\mathrm{mg} / \mathrm{L}$ in the Aab-e-Shifa water

\begin{tabular}{ll}
\hline Temperature $\left({ }^{\circ} \mathrm{C}\right)$ & 34 \\
\hline $\mathrm{Ca}$ & 49.98 \\
$\mathrm{Cd}$ & 0.006 \\
$\mathrm{Cr}$ & 0.008 \\
$\mathrm{Cu}$ & 0.012 \\
$\mathrm{Fe}$ & 0.031 \\
$\mathrm{~K}$ & 10.92 \\
$\mathrm{Mg}$ & 17.12 \\
$\mathrm{Mn}$ & 0.016 \\
$\mathrm{Na}$ & 37.12 \\
$\mathrm{Ni}$ & 0.018 \\
$\mathrm{Ph}$ & 7.84 \\
$\mathrm{Zn}$ & 6.73 \\
\hline
\end{tabular}

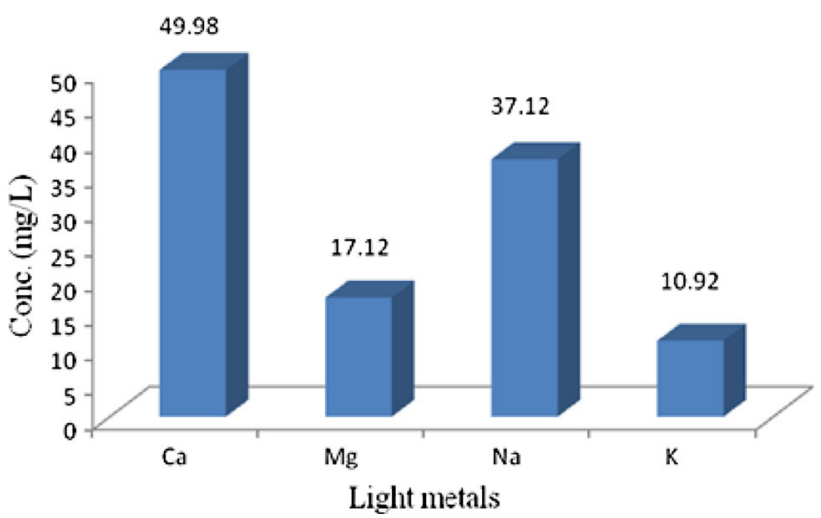

Fig. 7 Concentration of $\mathrm{Ca}, \mathrm{Mg}, \mathrm{Na}$, and $\mathrm{K}$ in Aab-e-Shifa water

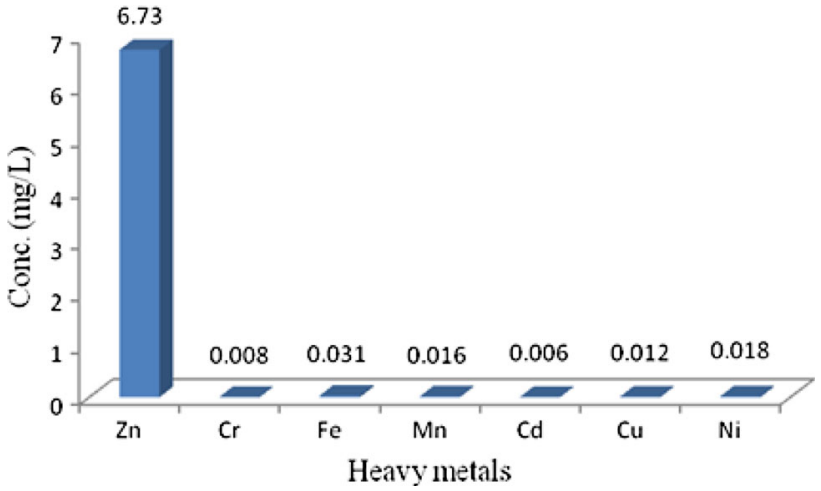

Fig. 8 Concentration of $\mathrm{Zn}, \mathrm{Cr}, \mathrm{Fe}, \mathrm{Mn}, \mathrm{Cd}, \mathrm{Cu}$, and $\mathrm{Ni}$ in Aab-eShifa spring

light elements including $\mathrm{Na}, \mathrm{K}, \mathrm{Ca}$, and $\mathrm{Mg}$. These elements are important promoters for healthy skin. The concentration of $\mathrm{Na}, \mathrm{K}, \mathrm{Ca}$, and $\mathrm{Mg}$ in Aab-e-Shifa water is $39.12,11.92,47.98$, and $17.12 \mathrm{mg} / \mathrm{L}$, respectively 
(Table 3 and Fig. 7). The alkalinity of the spring is due to these minerals in its water.

Particular interest to us is the $\mathrm{Zn}$ role in skin diseases and in wound healing. Generally, there are three categories of skin functions that are morphogenesis, repair and maintenance, and defense. Zn plays an important role in all of these processes. In human body, skin is a continual state of renewal, and it is a high demand of Zn-based enzymes and proteins that direct this renewal process (James et al. 2005).

Zinc is one of the trace elements and is the 23rd abundantly found element in the earth's crust (Jackson and Mills 2007). After Fe, $\mathrm{Zn}$ is the second most abundant trace element found in the human body, and the fourth most used element in the World (WHO 2001). An average $70 \mathrm{~kg}$ male approximately contains $2.3 \mathrm{~g}$ of $\mathrm{Zn}$. It is prevalent in the epidermis $(71 \mu \mathrm{g})$, where it is in high concentration, owing to the highly proliferative nature of this tissue (Molokia and Portony 1969). The ancient Egyptians have used Zn in healing of wounds, burns, and for treating various skin diseases (Lederer 1985). Today its wide use continues, treating many skin conditions with $\mathrm{Zn}$, over much of the human body. Zn plays catalytic, structural, and regulatory function in more than 300 enzymes that have been investigated in biological systems, involved in nucleic acid and protein metabolism, and energy production (Bruno and Angela 2009).

$\mathrm{Zn}$ deficiency is the major global public health problem that significantly impacts the developing countries. It is estimated that about half of the world's population has suboptimal zinc nutrition and thus global $\mathrm{Zn}$ deficiency is the 11th highest threat factor for diseases. In the developing countries, $\mathrm{Zn}$ deficiency is the fifth highest risk factor for diseases, even $75 \%$ of the population of some countries experiencing Zn deficiency (Nriagu 2011). Zinc deficiency may occur, due to inadequate intake or absorption, increased losses from the body, or increased requirements for it (Hambidge and Mills 1989; King et al. 2005; Prasad 1996). The recommended nutritional allowance for $\mathrm{Zn}$ is $8 \mathrm{mg} /$ day for women and $11 \mathrm{mg} /$ day for men (Panel on micronutrients 2000). Skin lesions poor wound healing is present in severe forms of $\mathrm{Zn}$ deficiency, but other symptoms include hair loss, acrodermatitis, and eczema. Even a small amount of $\mathrm{Zn}$ deficiency results in lymphopenia, a condition in which there exists an abnormally low number of lymphocytes in the blood needed to fight against infection and reduced immune capacity (Fraker et al. 1987). There are numerous articles that document the effect of $\mathrm{Zn}$ in acne and other skin diseases. $\mathrm{Zn}$ aids in the normal functioning of the oil-producing glands in the skin. Clinical studies carried out conclude that the healing power of $\mathrm{Zn}$ was evident only in those patients that were $\mathrm{Zn}$ deficient. Research area indicates that $\mathrm{Zn}$ is beneficial regardless of the patient $\mathrm{Zn}$ status (Robert and Rebecca 1999).

When a spring contains minerals and temperature above $25^{\circ} \mathrm{C}$, then it is considered as hot mineral springs (Nasermoaddeli and Kagamimori 2005; Shinko 2012; Andreassi and Flori 1996). Two important areas of benefit derive from taking bath in a natural mineral spring are the mineral contents and temperature, i.e., above $25{ }^{\circ} \mathrm{C}$. In the light of these findings, Aab-e-Shifa is a true natural thermal mineral spring because it contains curative mineral, i.e., $\mathrm{Zn}$, and has a temperature of $34{ }^{\circ} \mathrm{C}$. It has been investigated that minerals are transferred to the skin from mineral water and the blood stream by the process of osmosis and promote healthy skin (Javed et al. 2009). Temperature facilitates the dilation of skin for oxygen flow in the tissues that are being treated (Lotti and Ghersetich 1996a, 1996b). According to these facts, minerals $\mathrm{Na}, \mathrm{K}, \mathrm{Ca}, \mathrm{Mg}$, the most important antioxidant $\mathrm{Zn}$, and temperature $\left(34{ }^{\circ} \mathrm{C}\right)$ of $\mathrm{Aab}$ $e$-Shifa water are probably very much helpful for the treatment of many diseases especially for skin such as scabies, acne, ringworm, and arthritis.

The movement of water into and out of the body during mineral water bath is dependent upon the osmolality of the bath and fluid condition of the individual. Due to the osmolality of the bath, mineral water is either adsorbed or pulled from the body. Mineral adsorption through skin from thermal spring soaking is very small, and the amount adsorbed depends upon the concentration of the minerals in the spring and its chemical form. The dermatological curative effects of these minerals appear due to a local interaction between the mineral water and the skin surface (Nasermoaddeli and Kagamimori 2005). According to medical balneotherapists, even very small amounts of therapeutic minerals adsorbed through the skin into the body have a significant curative value (Javed et al. 2009; Eaton 2001).

\section{Conclusions}

Aab-e-Shifa spring water was analyzed for its various important minerals specifically $\mathrm{Zn}$ and its therapeutic properties. It was found that the water is curative to a number of skin diseases such as scabies, acne, ring worm, and arthritis due to its highest concentration of $\mathrm{Zn}$ $(6.73 \mathrm{mg} / \mathrm{L})$ as compared to other trace elements. $\mathrm{Zn}$ is a useful antioxidant, protects UV radiations, and thus provides defense to skin against the above-mentioned diseases. The water of the spring was also compared with the drinking water of the village houses and was found to be unique in this regard. Further study is required to evaluate the mechanism of $\mathrm{Zn}$ in healing various diseases. 
Open Access This article is distributed under the terms of the Creative Commons Attribution 4.0 International License (http:// creativecommons.org/licenses/by/4.0/), which permits unrestricted use, distribution, and reproduction in any medium, provided you give appropriate credit to the original author(s) and the source, provide a link to the Creative Commons license, and indicate if changes were made.

\section{References}

Andreassi L, Flori L (1996) Mineral water and spas in Italy. Clin Dermatol 14:627-632

Bruno B, Angela MR (2009) Chapter 7-Zinc, selenium and skin health: overview of their biochemical and physiological functions. Nutrition corn pp 139-158

Cataldi R, Hodgson SF, Lund JW (1999) Stories form heated earth: our geothermal heritage, pp 568-569

Center Geo-Heat (1993) Nine articles on hot springs, spas and balneology in the US. Geo-Heat Center Q Bull 14:32

Eaton RJ (2001) Balneology-healing hot springs, The Tecopa Hot Spring Mineral Water

Elizabeth FR, DeBuys HV, Madey DL, Pinnell SR (2002) Evidence supporting Zinc as an important antioxidant for skin. Int J Dermatol 41:606-611

Finkelman RB (2006) Health benefits of geologic materials and geologic processes. Int J Environ Resour Pub Health 3:338-342

Fraker PJ, Jardieu P, Cook J (1987) Zinc deficiency and immune function. Arch Dermatol 123:1699-1701

Hambidge KM, Mills CF (1989) Mild zinc deficiency in human subjects. Springer, New York, pp 281-296

Hotta A, Ishiguaro YA (1992) Guide to Japanese Hot Springs. Tokyo Japan, Kodansha Internatioal

Itallie V, Theodore B, Hadley L (1988) The best spas. Harper Row Publishers, New York, p 431

Jackson MJ, Mills CF (2007) Physiology of zinc: general aspects. Springer, London, pp 1-14

James RS, Marsh RG, Draelos ZD (2005) Zinc and skin health: overview of physiology and pharmacology. Dermatol Surg 31(7 pt 2):837-847
Javed A, Iqbal J, Asghar U, Khan FA, Munshi AB, Siddiqui I (2009) A study to evaluate the therapeutic properties of minerals of Mangophopir hot spring, Karachi. J Chem Soc Pak 31:396-401

Kaysing B (1990) Great hot springs of the west. Capra Press, Santa Barbara

King JC, Cousins RJ, Shils ME, Shike M, Ross AC (eds) (2005) Zinc. Lippincott Williams \& Wilkins, Baltimore, pp 271-285

Lederer J (1985) Le Zinc en pathologie et en biologie. Nauwelaerts, Bruxelles

Litton E (1990) The Hiker's guide to hot springs in the Pacific Northwest. Falcon Press, Helena

Lotti T, Ghersetich I (1996a) Mineral waters: instead of soap or better than soap. Clin Dermatol 14:101-104

Lotti T, Ghersetich I (1996b) How spring water works on the skin. Life Chem Rep 14:346-348

Lucio A, Laura F (1995) Mineral water and Spas in iseral. Clin Dermatol 14:627-632

Lund JW (1993) Geothermal spas in Chzecholovakia. Geotherm Trans 16:3-7

Molokia MH, Portony B (1969) Neutron action analysis of trace elements in the skin and Zinc in the normal skin. Br J Dermatol 81:759-762

Nasermoaddeli A, Kagamimori S (2005) Balneotherapy in medicine: a review. Environ Health Prev Med 10:171-179

Nriagu J (2011) Zinc Deficiency in Human health. Encyclopedia of Environmental Health pp 789-800

Panel on Micronutrients (2000) Zinc. National Academy press, Washington DC, pp 442-501

Prasad AS (1996) Zinc deficiency in women, infants and children. J Am Coll Nutr 15:113-120

Riyaz N, Arakkal FR (2011) Spa therapy in dermatology. Ind J Dermatol Venerol Leprol 77:128-134

Robert BS, Rebecca R (1999) Zinc: an essential micronutrient. Am Fam Physician 79:768-772

Sarnoff PM (1989) The ultimate spa book. Warner Books, New York 276

Shinko I (2012) Balneotherpy as Active Health Promotion in Japan. J Med Res Sci 2:5-9

World Health Organization (2001) Sources of human and environmental exposure. United Nations Environmental Program, International Labor Organization, pp 29-43 